\title{
Financial Feasibility Analysis for the Development of Honey Beeper and Bali Cattle Business Based on Forest Areas in Konawe Islands Regency
}

\author{
Musram Abadi ${ }^{*}$, Sudirman Zaid ${ }^{2}$, Rosmawati ${ }^{3}$, La Ode Nafiu ${ }^{4}$, Anita Indriasary ${ }^{5}$ \\ Faculty of Animal Husbandry, Universitas Halu Oleo, Kendari, 932321,4 \\ Faculty Economy and Business, Universitas Halu Oleo, $93232^{2}$ \\ Faculty of Fisheries and Marine Science, Universitas Halu Oleo, $93232^{3}$ \\ Faculty of Earth Sciences and Technology, Universitas Halu Oleo, $93232^{5}$ \\ $\left\{\right.$ musram.abadi79@uho.ac.id $\left.{ }^{1}\right\}$
}

\begin{abstract}
This research aims to determine the bussines development feasibility of the honey bee livestock and Bali cattle, Konawe Islands Regency, Southeast Sulawesi Province. This research is conducted in seven districts. Respondents are determined by Simple Random Sampling. 10 respondents will be randomly selected in each district, so that the total number of respondents in this study is 70 people. Honey bee livestocks and Bali cattle business will be analyzed using investment feasibility analysis, namely Net Present Value (NPV), Internal Rate of Return (IRR), Net Benefit Cost Ratio (BCR) and Pay Back Period (PBP). The results of the feasibility analysis of the business of Honeybees and Balinese cows show that the calculation of Net Present Value (NPV) obtained a positive NPV value at a discount rate of $56 \%$ of Rp. 106,378,-. For investment assessment using IRR criteria shows the number of IRR where NPV equals zero is $56.12 \%$. Then for the investment criteria $\mathrm{BCR}$ shows the value of $\mathrm{BCR}=1,002$. Furthermore, based on pbp assessment criteria the acceptance rate can cover the overall cost of investment for 3 Years and 6 Months. Based on the overall results of the investment criteria assessment, it can be concluded that the business of honeybeeper and Bali cattle based on forest areas in Konawe Islands Regency is worth implementing.
\end{abstract}

Keywords : Feasibility Analysis; HoneyBees; Bali Cattle

\section{Introduction}

Southeast Sulawesi Province through the Minister of Forestry Decree. No. 338 / MenhutVII / 2009 has 25 Forest Management Units (KPH) consisting of 15 Production Forest Management Units (KPHP) and 10 Protected Forest Management Units (KPHL). Among the 15 designated KPHPs, one of which is KPHP Unit XXIII Wawonii Island. Production Forest Management Unit (KPHP) Unit XXIII Wawonii Island is a Forest Management Unit (KPH) located in Konawe Islands Regency, which is a district that is part of Konawe Regency whose formation is based on Law Number 13 of 2013.

Decree of the Minister of Environment and Forestry No. 211 / Menlhk /Setjen/PLA.0/5/2018 dated 2 May 2018 concerning the determination of the Protected Forest Management Unit and Production Forest Management Unit of Southeast Sulawesi Province in the UPTD Unit XXIII area of Wawonii Island covering the entire administrative area of Konawe Islands Regency with an area of $\pm 36,563$ ha spread over 7 (seven) districts covering 
Protected Forests (HL) covering an area of $\pm 15,461$ ha $(42.29 \%)$, Limited Production Forests (HP) covering an area of $\pm 18,632$ ha $(50.96 \%)$ and Permanent Production Forests (HP) an area of $\pm 2,470$ ha $(6.76 \%)$.

Agroforestry is a man-made system and is a practical application of human interaction with natural resources around it. In principle, agroforestry is developed to solve problems in land use and rural development and to take advantage of the potential and opportunities that exist for human welfare with the support of the preservation of resources and their environment (Yuwariah, 2015).

Silvopasture or some call livestock forest, is a form of agroforestry which is a mixture of forestry and livestock activities. This model is suitable to be developed in areas where the population activates livestock business, where pasture is a problem. In the forest area, planting fodder grass or providing forage that grows naturally.

Through the practice of Silvopasture, which is a cultivation technology by combining livestock and forestry in order to optimize the use of increasingly limited land, it is also useful for creating opportunities to increase the potential for human welfare and preservation of natural resources, as a support for sustainable livestock. Productivity, diversity, independence, and stability are potential advantages of Agroforestry in contributing to increased income, national independence, and environmental improvement (Yuwariah, 2015).

Potential that can be used as a mainstay in the development of silvopasture in Konawe Islands Regency is honey beeper and Bali cattle. The diversification of the two efforts has been carried out by some people in Konawe Islands Regency, especially by people who work as farmers and breeders. Based on the description of the background, a study was conducted on the "Feasibility Analysis of Silvopasture (Honey Bees and Bali Cattle-) in Konawe Islands Regency".

\section{Research Method}

\subsection{Location and Time of Research}

This research was conducted in Konawe Islands Regency, Southeast Sulawesi Province, to be precise in seven sub-districts, namely West Wawonii, South Wawonii, Central Wawonii, Southeast Wawonii, East Wawonii, North East Wawonii, and North Wawonii Sub-districts. The selection of the seven areas is purposive (Purposife Sampling) or specially selected for research purposes with the objective consideration that the seven sub-districts are the basis for Bali cattle and honey bee breeders. The research was conducted for 4 months from June 2020 to September 2020.

\subsection{Types and Sources of Data}

Based on the type of data used in this study, it consists of primary data and secondary data (Sugiyono, 2014). Primary data is data obtained directly based on field surveys from the main source. Secondary data is data that has been collected by data collection agencies and published to the user community.

The data required includes: production results, product selling price and input data which are farmer expenses. Meanwhile, to support this research, secondary data is also needed, namely written data from various parties to support this research.

\subsection{Research Respondents}

Respondents in this study were honey beeper and Bali cattle breeders. Respondents were determined by simple random sampling 10 respondents be randomly selecte in each subdistrict, so that the total number of respondents in this study is 70 people.

\subsection{Method of collecting data}


The data collection methods used in this research were survey, observation and documentation. Interviews were conducted directly with respondents of honey beeper and Bali cattle breeders using pre-arranged questions or questionnaires. Interviews were conducted simultaneously with field observations. Documentation carried out by conducting a survey of data related to this study, analyzing the data, developing theories and reviewing it by linking previous studies.

\subsection{Data analysis}

The data obtained from the research results are simplified in tabulated form based on grouping so that it is easy to calculate the analysis and discussion. Data analysis was performed using quantitative methods using the help of Microsoft Excel application program. Both types of business using business projection analysis with a project life of five years. The projection of the development of the honey beeper and Bali cattle business within five years aims to see a picture of the financial projection which consists of several components of financial analysis, namely;

1. Projected investment needs;

2. Income projections;

3. Cost projections;

4. Cash flow projections;

5. Projection of profit and loss;

6. Balance sheet projections;

7. Investment feasibility analysis.

The analysis used in the assessment of the feasibility of investing in the development of the honey beeper and Bali cattle business within five years is; Net Present Value (NPV), Internal Rate of Return (IRR), Net Benefit Cost Ratio (NBCR) and Pay Back Period (PBP). In the calculation of financial analysis, there is no separation of financial analysis calculations for each business venture, namely; honey beeper and Bali cattle, but will be combined. The basis for the consideration of the consolidation of calculations is; (1) honey beeper and Bali cattle business is a diversification business; (2) these two businesses are in the same concession area; and (3) there are several component items which are shared costs.

\subsection{Net Present Value (NPV)}

NPV calculation in an investment appraisal is a practical way to find out whether a project is being carried out profitable or not (Arshad, 2012). The advantage of a business project is the amount of revenue minus the financing issued. Thus, if a project has an NPV of less than zero, the project or business is not feasible to run. Meanwhile, if the NPV is more than zero, then the project or business is feasible to run. The NPV formula in a project or business is written by Nurmalina (2014) as follows:

$$
\begin{aligned}
& \qquad \mathrm{NPV}=\sum_{\mathrm{t}=0}^{\mathrm{n}} \frac{\mathrm{Bt}-\mathrm{Ct}}{\left(1+\mathrm{i}^{\mathrm{t}}\right)} \\
& \text { Information : } \\
& \mathrm{Bt} \quad=\text { Benefits in years } \\
& \mathrm{Ct} \quad=\text { Cost in year } \mathrm{t} \\
& \mathrm{t} \quad=\text { Year of business activity }(\mathrm{t}=0,1,2,3,4,5, \ldots \ldots) \\
& \mathrm{i} \quad=\text { The discount rate (accourding to KUR } 12 \%)
\end{aligned}
$$

\subsection{Internal Rate of Return (IRR)}

IRR is an internal rate of return whose calculation aims to determine the percentage of profits from a business project in each year (Kriswanto, 2011). In addition, IRR is also a measure of a project's ability to repay loan interest. Basically, IRR shows the interest rate that results in NPV equal to zero. If this interest rate is higher, then the investment can be said to 
be feasible and if the interest rate is lower, then the investment is not feasible. The formulas used to calculate the IRR analysis in Adalina (2008) are:

Information :

$$
\operatorname{IRR}=\mathrm{i}_{1}+\frac{\mathrm{NPV}_{1}}{\left(\mathrm{NPV}_{1}-\mathrm{NPV}_{2}\right)}\left(\mathrm{i}_{2}-\mathrm{i}_{1}\right)
$$

$$
\begin{array}{ll}
\mathrm{NPV}_{1} & =\text { NPV which is positive } \\
\mathrm{NPV}_{2} & =\text { NPV which is negative } \\
\mathrm{i}_{1} & =\text { The interest rate when generating a positive NPV } \\
\mathrm{i}_{2} & =\text { The interest rate when generating a negative NPV }
\end{array}
$$

\subsection{Net Benefit Cost Ratio (NBCR)}

NBCR is the amount of additional benefit for each additional cost of one unit. NBCR is a comparison between the present value of a positive net benefit and a negative net benefit. If the NBCR value is greater than 1, the project is said to be profitable. But if it is less than 1 then the project should not be continued because it is not feasible. The formula used to find NBCR is as follows:

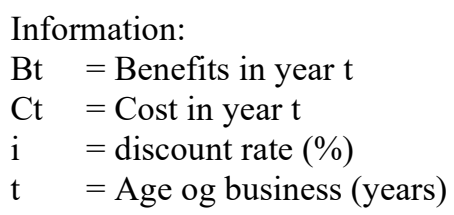

$$
\text { Net } B / C=\frac{\sum_{t=1}^{n} \frac{B t-C t}{(1+i) t}}{\sum_{t=1}^{n} \frac{C t-B t}{(1+i) t}}
$$

Decision-making criteria for NBCR:

$\mathrm{NBCR}>1=$ It means that the business or project is feasible or feasible

NBCR $<1=$ It means that the business or project is not feasible or not feasible

$\mathrm{NBCR}=1=$ It means that the business or project is in BEP

\section{Pay Back Period (PBP)}

PBP is the initial fee refund period. Rachadian et al., (2013) revealed that the advantage of the PBP method is that it is easy to use and calculate, useful for choosing which investment has the fastest recovery of capital funds. The recovery period for capital can be used to predict the risk of uncertainty in the future, and the fastest recovery period has less risk than the relatively long recovery period. While the weaknesses are ignoring changes in the value of money from time to time, ignoring cash flow after capital recovery is achieved, ignoring the residual value of the process and often trapping when the cost of capital or credit interest is not factored into the cash flow, causing the business to be illiquid. PBP is formulated by:

Information:

$$
\mathrm{PBP}=\mathrm{T}_{\mathrm{p}-1}+\frac{\sum_{\mathrm{i}=1}^{\mathrm{n}} \mathrm{i}_{1}-\sum_{\mathrm{i}=1}^{\mathrm{n}} \mathrm{B}_{\mathrm{icp}-1}}{\mathrm{~B}_{\mathrm{p}}}
$$

PBP = Pay Back Period

$\mathrm{T}_{\mathrm{p}-1}=$ Year before there was PBP

$\mathrm{I}_{1} \quad=$ The investment amount has been discounted

$\mathrm{B}_{\text {icp- } 1}=$ Amount of benefits that have been discounted before PBP

$\mathrm{Bp}=$ Number of benefetis on PBP 


\section{Results and Discussions}

\subsection{Projected Investment Needs}

The first stage of understanding the feasibility study or business plan is the total investment required. It is necessary to know the details of this investment cost to find out the reasonableness of each investment cost item (Hutrema , 2010). At this stage, needed for each business will be identified, namely honey beeper and Bali cattle to start a business, which will then be carried out to determine the Estimated Own Price (HPS) for each equipment and equipment needed. Because this business plan is a diversification business that is in one area, there will be joint assets between the honey beeper and the Bali cattle business. Projection initial needs business investment honey bee and Bali cattle is presented in Table 1 .

Table 1. Initial Investment Needs for Honey Bee and Bali Cattle Business

\begin{tabular}{|c|c|c|c|c|c|}
\hline No & Type & Capacity & $\begin{array}{l}\text { Unit Price } \\
\text { (Rp) }\end{array}$ & $\begin{array}{c}\text { Amount } \\
\text { (Rp) }\end{array}$ & $\begin{array}{c}\text { Monthly } \\
\text { Depreciation }\end{array}$ \\
\hline \multicolumn{6}{|c|}{ JOINT INVESTMENT } \\
\hline 1 & $\begin{array}{l}\text { Location Fencing Fee } \\
\text { (2 Ha) }\end{array}$ & 1 Unit & 10.000 .000 & 10.000 .000 & 166.667 \\
\hline \multicolumn{6}{|c|}{ HONEY BEEPER } \\
\hline 2 & Bee House & 30 Units & 750.000 & 22.500 .000 & 187.500 \\
\hline 3 & Bee House Ward & $\begin{array}{c}1 \\
\text { Package }\end{array}$ & 2.500 .000 & 2.500 .000 & 20.833 \\
\hline \multirow[t]{2}{*}{4} & $\begin{array}{l}\text { Cultivation and } \\
\text { Harvest Equipment }\end{array}$ & $\begin{array}{c}1 \\
\text { Package }\end{array}$ & 1.500 .000 & 1.500 .000 & 12.500 \\
\hline & Total & & & 26.500 .000 & 220.833 \\
\hline \multicolumn{6}{|c|}{ BALI CATTLES } \\
\hline 5 & $\begin{array}{l}\text { Bali Cattle Seeds } \\
\text { (Age } 24 \text { months; } 12 \\
\text { months; } 0 \text { months) }\end{array}$ & 6 tails & 6.000 .000 & 24.000 .000 & \\
\hline 6 & Cost of making cages & 1 Unit & 5.000 .000 & 5.000 .000 & 83.333 \\
\hline & Total & & & 29.000 .000 & \\
\hline \multicolumn{2}{|c|}{$\begin{array}{l}\text { FIRST YEARS } \\
\text { OPERATIONAL COSTS }\end{array}$} & 1 Paket & 35.650 .833 & 35.650 .833 & \\
\hline \multicolumn{4}{|c|}{ Total Initial Investment Costs } & 101.150 .833 & 470.833 \\
\hline
\end{tabular}

Based on Table 1, it is known that the total amount of initial investment required for the honey beeper and Bali cattle business plan is Rp. 101,150,833 , - where this value includes operating capital for the first year, which is the costs incurred for the first year of business operations plus the projected depreciation expense for each depreciation asset or equipment in one year. The technique of calculating depreciation costs uses the proportional method where the depreciation age is set for 5 years.

Joint investment is a projection of investment costs that are used jointly by each livestock business, namely honey beeper and Bali cattle. This investment cost is the cost of fencing the designated area of 2 hectares, which is Rp. 10,000,000, -

For the honey beeper business, the initial investment requirement is Rp. 26,500,000, This amount includes the purchase cost of 30 units of bee houses with a per-unit price of Rp. $750,000,-$ / unit. In the initial investment requirement for honey beeper, a bee house ward 
costs Rp. 2,500,000 , - and the cost of purchasing cultivation and harvesting equipment is Rp. $1,500,000$,

Bali cattle for the beginning of the investment year requires Rp. 29,000,000 , - consisting of Rp. 24,000,000, - for the purchase of 6 oaks or calves of Bali cattle. The calves of Bali cattle that are planned to be purchased earlier in the year of investment are 2 Bali cattle aged 24 months, 2 Bali cattle 12 months old, and 2 Bali cattle aged 0-6 months. The consideration used in the purchase of calf breeds is to ensure continuity of reproduction every year considering the reproductive period of cattles is 12 months. In addition, there is also a cattle pen making cost of Rp. 5,000,000, - . Since the production projection plan is expected to be obtained in the middle and end of the year while the operational costs have to be spent starting from the beginning of the investment, the first year operational costs of Rp. 35,650,833, - .

\subsection{Income Projections}

The projection of revenue from the honey beeper and Bali cattle business within five years is prepared according to the projections and assumptions of the respective revenue plans, both honey beeper and Bali cattles. Therefore, a detailed description of the revenue projection mechanism for the two businesses will be carried out.

\subsection{Honey bee}

The results of data collection regarding honey beeper provide information that the potential for harvest of honey beeper in each year is 3 times (once every 4 months), with an average amount of honey per harvest is 1.5 liters, so the potential for honey production in 1 year for one bee house is 4.5 liters / year. If it is assumed that the price per liter of honey follows the market price, namely; Rp. 200,000, - / liter, the projected annual income of honey beeper is Rp. 900,000, -. If the honey beeper for the start-up phase is 30 bee houses, the projected total annual income is Rp. 900,000 , - x 30 bee houses = Rp. 27,000,000, - per year. This projection of total income is assumed to remain constant over a period of 5 years.

\subsection{Bali Cattle}

The initial assumptions built in the calculation of the projection of the Bali cattle income are;

a. The number of calf prepared at the beginning of the first year is 6 calf consisting of 2 cattle aged 24 months; 2 cattle aged 12 months; and 2 calf aged 0-6 months.

b. The determination of the number of cattle seeds at the beginning of the year is to ensure continuity of production every year.

c. For reproductive purposes, a cattle cutting process will be carried out using the injection mating technique.

d. Ready-to-inject cows are cattle with an age of 24 months, with the length of the process from injection mating, pregnancy to calving is 11-12 months so it is assumed that by the 12 th month the cattle have reproduced.

e. It is assumed that within 5 years all calves born are females.

f. Prices for cattle are determined based on market prices, namely; - $\quad$ Age 0 - 6 months $=$ Rp. 2,000,000, - head

- $\quad$ Age 12 months = Rp. 4,000,000, - / head

- $\quad$ Age 24 months = Rp. 6,000,000, - head

- $\quad 36$ months old $\quad=$ Rp. 8,000,000, - head

- 48 months old = Rp. 10,000,000, - head

-Age 60 months $=$ Rp. 10,000,000, - / head

g. After the cattle is 60 months old or it is assumed that it has given birth 3 times, it will be rejuvenated by replacing it with a cattle that is 24 months old. Rejuvenation is projected to occur at the end of the third year. 
h. The difference between the selling price and the buying price of the cattle at the time of rejuvenation will then be included as revenue in the form of receiving the difference in replanting.

i. Because the cattle business is classified as a long-term investment, the calculation of financial analysis used is cycle analysis, where 1 cycle is set for 5 years.

Impact usage cycle analysis is a form of admission every year is called as Revenue Shadow (shadow income), which means that the sale of the production is only done at the end of the cycle, while the annual production estimates are converted into rupiah (money).

Based on these assumptions, the projection of cattle reproduction at the end of the year within 5 years can be seen in Table 2 .

Table 2. Projection of Cattle Reproduction at the End of the Year in a Period of 5 Years

\begin{tabular}{lccccccc}
\hline \multirow{2}{*}{ Years } & \multicolumn{7}{c}{ Projection of Number of Cattle by Age } \\
\cline { 2 - 7 } & $\begin{array}{c}\mathbf{6 0} \\
\text { months }\end{array}$ & $\begin{array}{c}\mathbf{4 8} \\
\text { months }\end{array}$ & $\begin{array}{c}\mathbf{3 6} \\
\text { months }\end{array}$ & $\begin{array}{c}\mathbf{2 4} \\
\text { months }\end{array}$ & $\begin{array}{c}\mathbf{1 2} \\
\text { months }\end{array}$ & 0 months & Amount \\
\hline First & - & - & 2 & 2 & 2 & 2 & 8 \\
Second & - & 2 & 2 & 2 & 2 & 4 & 12 \\
Third & - & 2 & 2 & 4 & 4 & 6 & 18 \\
Fourth & - & 2 & 4 & 6 & 6 & 8 & 26 \\
Fifth & - & 4 & 6 & 8 & 8 & 12 & 38 \\
\hline
\end{tabular}

Based on Table 2 it can be seen that at the end of the first year the number of cattle is 8 heads (assuming 2 cattle aged 24 months have reproduced each 1). At the end of the third year, there are 2 cattle aged 60 years ( 3 times giving birth), so that rejuvenation is carried out by selling the cattle according to the market price (Rp. 10,000,000) and replacing them with cattle aged 24 months at a price of Rp. 6,000,000, -, resulting in a difference of Rp. 4,000,000, - / head or a total of Rp. 8,000,000, -. Likewise for the end of the fourth and fifth years.

After the projection of cattle reproduction is carried out in a period of 5 years, then the annual shadow income is determined. The process of determining shadow income is carried out by first estimating the price of each cow each year based on the projected number of cattle per year. Referring to the market price for cattle based on age as previously explained, the estimated shadow income for a period of 5 years can be seen in Table 3 .

Table 3. Estimated Shadow Income of Cattle at the End of the Year in a Period of 5 Years

\begin{tabular}{|c|c|c|c|c|c|c|c|}
\hline \multirow[b]{2}{*}{ Years } & \multicolumn{6}{|c|}{ Projection of Number of Cattle by Age } & \multirow[b]{2}{*}{ Amount } \\
\hline & $\begin{array}{c}60 \\
\text { months }\end{array}$ & $\begin{array}{c}48 \\
\text { months }\end{array}$ & $\begin{array}{c}36 \\
\text { months }\end{array}$ & $\begin{array}{c}24 \\
\text { months }\end{array}$ & $\begin{array}{c}12 \\
\text { months }\end{array}$ & 0 months & \\
\hline First & - & - & $\begin{array}{c}2(8 \\
\text { milion })\end{array}$ & $\begin{array}{c}2(6 \\
\text { milion })\end{array}$ & $\begin{array}{c}2(4 \\
\text { milion })\end{array}$ & $\begin{array}{c}2(2 \\
\text { milion })\end{array}$ & 8 \\
\hline Second & - & $\begin{array}{c}2(10 \\
\text { milion })\end{array}$ & $\begin{array}{c}2(8 \\
\text { milion })\end{array}$ & $\begin{array}{c}2(6 \\
\text { milion })\end{array}$ & $\begin{array}{c}2(4 \\
\text { milion })\end{array}$ & $\begin{array}{c}4(2 \\
\text { milion) }\end{array}$ & 12 \\
\hline Third & - & $\begin{array}{c}2(10 \\
\text { milion })\end{array}$ & $\begin{array}{c}2(8 \\
\text { milion })\end{array}$ & $\begin{array}{c}4(6 \\
\text { milion) }\end{array}$ & $\begin{array}{c}4(4 \\
\text { milion) }\end{array}$ & $\begin{array}{c}6(2 \\
\text { milion })\end{array}$ & 18 \\
\hline Fourth & - & $\begin{array}{c}2(10 \\
\text { milion })\end{array}$ & $\begin{array}{c}4(8 \\
\text { milion })\end{array}$ & $\begin{array}{c}6(6 \\
\text { milion })\end{array}$ & $\begin{array}{c}6(4 \\
\text { milion })\end{array}$ & $\begin{array}{c}8(2 \\
\text { milion })\end{array}$ & 26 \\
\hline Fifth & - & $\begin{array}{c}4(10 \\
\text { milion })\end{array}$ & $\begin{array}{c}6(8 \\
\text { milion }) \\
\end{array}$ & $\begin{array}{c}8(6 \\
\text { milion) }\end{array}$ & $\begin{array}{c}8(4 \\
\text { milion) }\end{array}$ & $\begin{array}{c}12(2 \\
\text { milion })\end{array}$ & 38 \\
\hline
\end{tabular}

Based on the estimated shadow income in the table above, then it can be seen the projected shadow income at the end of the year in a period of 5 years in Table 4.

Table 4. Projection of Shadow Income Amounts at the End of the Year in a Period of 5 Years (in rupiah)

\begin{tabular}{|c|c|c|c|c|c|c|c|}
\hline \multirow[b]{2}{*}{ Years } & \multicolumn{6}{|c|}{ Projection of Number of Cattle by Age } & \multirow[b]{2}{*}{ Amount } \\
\hline & $\begin{array}{c}60 \\
\text { months }\end{array}$ & $\begin{array}{c}48 \\
\text { months }\end{array}$ & $\begin{array}{c}36 \\
\text { months }\end{array}$ & $\begin{array}{c}24 \\
\text { months }\end{array}$ & $\begin{array}{c}12 \\
\text { months }\end{array}$ & $\begin{array}{c}\mathbf{0} \\
\text { months }\end{array}$ & \\
\hline First & - & - & 16.000 .000 & 12.000 .000 & 8.000 .000 & 4.000 .000 & 40.000 .000 \\
\hline
\end{tabular}




\begin{tabular}{ccrrrrrr} 
Second & - & 20.000 .000 & 16.000 .000 & 12.000 .000 & 8.000 .000 & 4.000 .000 & 60.000 .000 \\
Third & - & 20.000 .000 & 16.000 .000 & 24.000 .000 & 16.000 .000 & 12.000 .000 & 88.000 .000 \\
Fourth & - & 20.000 .000 & 32.000 .000 & 36.000 .000 & 24.000 .000 & 16.000 .000 & 128.000 .000 \\
Fifth & - & 40.000 .000 & 48.000 .000 & 48.000 .000 & 32.000 .000 & 24.000 .000 & 192.000 .000 \\
\hline
\end{tabular}

Based on the projected amount of shadow income at the end of each year in a period of 5 years in Table 4, it can be seen that at the end of the fifth year there is a projection of Rp. $192,000,000$, - which means that this value is the total value of investment receipts in one investment cycle (5 years).

Therefore, the calculation of the projected amount of shadow income each year still contains the initial investment value, namely; the purchase value of cattle seeds at the beginning of the investment year (first year) is Rp. 24,000,000 , - (2 cattle aged 24 months; 2 cattle aged 12 months; 2 calf aged 0-6 months), then this value must be calculated first to obtain the actual shadow income for each end of the year. Based on this explanation, the actual shadow income value for each year end in a period of 5 years is; (1) End of First Year; Rp. 40,000,000 - Rp. 24,000,000 = Rp. 16,000,000, - ; (2) End of Second Year; Rp. 60,000,000 - Rp. 24,000,000 = Rp. 36,000,000, - ; (3) End of Third Year; Rp. 88,000,000 Rp. $24,000,000=$ Rp. 64,000,000, - ; (4) End of Fourth Year; Rp. 128,000,000 - Rp. $24,000,000=$ Rp. 104,000,000, - ; and (5) End of Fifth Year; Rp. 192,000,000 - Rp. $24,000,000=$ Rp. $168,000,000,-$.

Based on the projected revenue for each honey beeper and Bali cattle, the total annual income, can be seen in Table 5 .

Table 5. Projection of Total Income of Honey Beeper and Bali Cattle at the End of the Year in a Period of 5 Years (in rupiah)

\begin{tabular}{cccc}
\hline Years & Honey Bee & Bali Cattle & Total Projected Income \\
\hline 1 & 27.000 .000 & 16.000 .000 & 43.000 .000 \\
2 & 27.000 .000 & 36.000 .000 & 63.000 .000 \\
3 & 27.000 .000 & 64.000 .000 & 91.000 .000 \\
4 & 27.000 .000 & 104.000 .000 & 131.000 .000 \\
5 & 27.000 .000 & 168.000 .000 & 195.000 .000 \\
\hline
\end{tabular}

\subsection{Cost Projection}

The projection of annual costs for honey beeper and Bali cattle in this business plan is carried out collectively with several considerations previously explained. For this reason, the cost components that will be incurred each year will be described as follows:

1. Labor costs; is the cost incurred to pay the salary of 1 person. This workforce is assigned to; (a) maintain and monitor the cleanliness and safety of the bees house; (b) harvest honey by squeezing technique; (c) feeding, drinking, cleaning the stables, shepherding in the morning and shepherding in the evening. The workforce salary is set at Rp. 1,000,000, - / month so that the total annual worker's salary is Rp. $12,000,000,-$

2. Cost of depreciation; is a fee imposed on assets that have a limited economic age in use. Assets that are subject to depreciation expense in this case are (a) fence for an area of 2 hectares with an economic age of 5 years, namely; Rp. 166,667, -; (b) 30 units of bee houses with an economic age of 10 years, namely; Rp. 187,500, -; (c) 1 unit bee ward house with an economic age of 10 years, namely; Rp. 20,833, -; (d) honey bee cultivation and harvesting equipment with an economic age of 10 years, namely; Rp. 12,500; (e) 1 unit of cow shed with an economic age of 5 years, namely; Rp. 83,333, - so that the total value of the depreciation expense component per year is; Rp. 470,833, - 
3. Electricity cost; is the cost of purchasing electricity pulses for installing lights in the cow shed and bee house ward, estimated at Rp. 50,000, - / month or Rp. 600,000, - / year.

4. Cattle Feed Cost; represents the cost of providing beef food. The amount of feed for each age is different. (a) the amount of feed for calves is an average of $500 \mathrm{~kg}$ per 2 head per month; (b) the amount of feed for calves is $1,000 \mathrm{~kg}$ per 2 head per month; and (c) the amount of feed for adult cattle is $1,500 \mathrm{~kg}$ per 2 head per month. If it is assumed that the price per $\mathrm{kg}$ of feed for cattle is Rp. 500, -, then the cost of feed for; (a) a calf per month is Rp. 500, - x $250 \mathrm{~kg}=\mathrm{Rp} .125,000$, - or Rp. 1,500,000 , - per year; (b) per month for calf cattle is Rp. 500, - x $500 \mathrm{~kg}=\mathrm{Rp} .250,000$, - or Rp. $3,000,000$, - per year; and (c) a per month per month for adult cattle is Rp. 500, - $\mathrm{x}$ $750 \mathrm{~kg}=$ Rp. 375,000 , - or Rp. 4,500,000, - per year, so the details of the overall cost of feed for the first year to the fifth year are presented in Table 6 .

Table 6.Projection of Total Annual Cost of Bali Cattle Feed in a 5 Year Period (in rupiah)

\begin{tabular}{|c|c|c|c|c|c|c|c|}
\hline \multirow[b]{2}{*}{ Years } & \multicolumn{6}{|c|}{ Projection of Number of Cattle by Age } & \multirow[b]{2}{*}{$\underset{t}{\text { Amoun }}$} \\
\hline & $\begin{array}{c}60 \\
\text { months }\end{array}$ & $\begin{array}{c}48 \\
\text { months }\end{array}$ & $\begin{array}{c}36 \\
\text { months }\end{array}$ & $\begin{array}{c}24 \\
\text { months }\end{array}$ & $\begin{array}{c}12 \\
\text { months }\end{array}$ & $\begin{array}{c}0 \\
\text { months }\end{array}$ & \\
\hline First & - & - & & $\begin{array}{c}2 \\
(4.500 .000 \\
)\end{array}$ & $\begin{array}{c}2 \\
(3.000 .000 \\
)\end{array}$ & $\begin{array}{c}2 \\
(1.500 .000 \\
)\end{array}$ & $\begin{array}{c}18.000 . \\
000\end{array}$ \\
\hline $\begin{array}{c}\text { Secon } \\
\mathrm{d}\end{array}$ & - & - & $\begin{array}{c}2 \\
(4.500 .000)\end{array}$ & $\begin{array}{c}2 \\
(4.500 .000 \\
)\end{array}$ & $\begin{array}{c}2 \\
(3.000 .000 \\
)\end{array}$ & $\begin{array}{c}2 \\
(1.500 .000 \\
)\end{array}$ & $\begin{array}{c}27.000 . \\
000\end{array}$ \\
\hline Third & - & $\begin{array}{c}2 \\
(4.500 .0 \\
00)\end{array}$ & $\begin{array}{c}2 \\
(4.500 .000)\end{array}$ & $\begin{array}{c}2 \\
(4.500 .000 \\
)\end{array}$ & $\begin{array}{c}2 \\
(3.000 .000 \\
)\end{array}$ & $\begin{array}{c}4 \\
(1.500 .000 \\
)\end{array}$ & $\begin{array}{c}39.000 . \\
000\end{array}$ \\
\hline Fourth & - & $\begin{array}{c}2 \\
(4.500 .0 \\
00)\end{array}$ & $\begin{array}{c}2 \\
(4.500 .000)\end{array}$ & $\begin{array}{c}4 \\
(4.500 .000 \\
)\end{array}$ & $\begin{array}{c}4 \\
(3.000 .000 \\
)\end{array}$ & $\begin{array}{c}6 \\
(1.500 .000 \\
)\end{array}$ & $\begin{array}{c}57.000 . \\
000\end{array}$ \\
\hline Fifth & - & $\begin{array}{c}2 \\
(4.500 .0 \\
00)\end{array}$ & $\begin{array}{c}4 \\
(4.500 .000)\end{array}$ & $\begin{array}{c}6 \\
(4.500 .000 \\
)\end{array}$ & $\begin{array}{c}6 \\
(3.000 .000 \\
)\end{array}$ & $\begin{array}{c}8 \\
(1.500 .000 \\
)\end{array}$ & $\begin{array}{c}84.000 . \\
000\end{array}$ \\
\hline
\end{tabular}

1. IB Officer Fee; is the cost of injecting a cattle for mating injection. The cost for each injection is Rp. 100.000 , -, so that by referring to the number of cattle ready for injection (24 months and above) per year, the amount of injection costs per year is; (a) The first year; 2 tails x Rp. 100,000, - = Rp. 200,000, -; (b) Second year; 4 heads x Rp. 100,000, - = Rp. 400,000, -; (c) Third year; 6 heads x Rp. 100,000, - = Rp. 600,000, -; (d) Fourth year; 8 tails x Rp. 100,000, - = Rp. 800,000, -; and (e) fifth year; 12 heads $x$ Rp. 100,000, - = Rp. 1,200,000, -

2. Cattle Medicine Costs; represents the costs incurred to purchase medicines for cattles. The estimated cost of the medicines is Rp. 20,000, - / head / month, or Rp. 240,000, - / head / year. Based on the number of cattles in each year, the estimated cost of medicines is; (a) The first year; 6 heads x Rp. 240,000, - = Rp. 1,440,000, -; (b) Second year; 8 tails x Rp. 240,000, - = Rp. 1,920,000, -; (c) Third year; 12 heads x Rp. 240,000, - = Rp. 2,880,000, -; (d) Fourth year; 18 heads x Rp. 240,000, - = Rp. 4,320,000, -; and (e) fifth year; 26 heads x Rp. 240,000, - = Rp. 6,240,000, -

3. Cattle Vitamins and Minerals Costs; represents the costs incurred for the purchase of vitamins and minerals for cattles. The cost of vitamins and minerals is estimated at Rp. 20,000, - / head / month, or Rp. 240,000, - / head / year. Based on the number of cattles in each year, the estimated cost of vitamins and minerals is; (a) The first year; 6 heads x Rp. 240,000, - = Rp. 1,440,000, -; (b) Second year; 8 tails x Rp. 240,000, - = Rp. 1,920,000, -; (c) Third year; 12 heads x Rp. 240,000, - = Rp. 2,880,000, -; (d) Fourth 
year; 18 heads x Rp. 240,000, - = Rp. 4,320,000, -; and (e) fifth year; 26 heads x Rp. 240,000, - = Rp. 6,240,000, - .

Land Processing Costs; represents the costs incurred for processing a 2 hectare land in the form of land stretching. This land cultivation cost is only spent at the beginning of the first year with a value of Rp. 1,500,000, -

Based on the description regarding the components and the amount of these costs, the total cost for each year can be obtained which is presented in Table 7.

Table 7. Projection of Total Annual Cost of Honey Beeper and Bali Cattle in a 5 Year Period (in rupiah)

\begin{tabular}{|c|c|c|c|c|c|c|}
\hline \multirow{2}{*}{ No } & \multirow{2}{*}{ Cost } & \multicolumn{5}{|c|}{ Years } \\
\hline & & 1 & 2 & 3 & 4 & 5 \\
\hline 1 & Labor costs & 12.000 .000 & 12.000 .000 & 12.000 .000 & 12.000 .000 & 12.000 .000 \\
\hline 2 & $\begin{array}{l}\text { Cost of } \\
\text { depreciation }\end{array}$ & 470.833 & 470.833 & 470.833 & 470.833 & 470.833 \\
\hline 3 & $\begin{array}{l}\text { Electricity } \\
\text { cost }\end{array}$ & 600.000 & 600.000 & 600.000 & 600.000 & 600.000 \\
\hline 4 & $\begin{array}{l}\text { Cattle feed } \\
\text { cost }\end{array}$ & 18.000 .000 & 27.000 .000 & 39.000 .000 & 57.000 .000 & 84.000 .000 \\
\hline 5 & IB Officer fee & 200.000 & 400.000 & 600.000 & 800.000 & 1.200 .000 \\
\hline 6 & Drug cost & 1.440 .000 & 1.920 .000 & 2.880 .000 & 4.320 .000 & 6.240 .000 \\
\hline 7 & $\begin{array}{l}\text { Vitamins and } \\
\text { Minerals cost }\end{array}$ & 1.440 .000 & 1.920 .000 & 2.880 .000 & 4.320 .000 & 6.240 .000 \\
\hline 8 & $\begin{array}{l}\text { Land } \\
\text { processing } \\
\text { costs }\end{array}$ & 1.500 .000 & - & - & - & - \\
\hline & Total & 35.650 .833 & 44.310 .833 & 58.430 .833 & 79.510 .833 & 110.750 .833 \\
\hline
\end{tabular}

\subsection{Cash Flow Projection}

Cash flow (cash flow statement or statement of cash flows) is part of a company's financial statements produced during an accounting period that shows the company's cash inflows and outflows (Hutrema, 2010). Based on the projection results of investment needs, capital structure, income, and expenses, the projection of cash flow for each year in 5 years is presented in Table 8.

Table 8. Projection of Cash Flows of Honey Beeper and Bali Cattle Annuals in a 5 Year Period (in rupiah)

\begin{tabular}{|c|c|c|c|c|c|c|}
\hline \multirow{2}{*}{ No } & \multirow{2}{*}{ Information } & \multicolumn{5}{|c|}{ Years } \\
\hline & & 1 & 2 & 3 & 4 & 5 \\
\hline A & $\begin{array}{ll}\text { Initial } & \text { Cash } \\
\text { Position } & \end{array}$ & - & 7.349 .167 & 26.038 .333 & 66.607 .500 & 126.096 .667 \\
\hline \multirow[t]{6}{*}{ B } & Cash Inflow & & & & & \\
\hline & Authorized capital & 101.150 .833 & - & - & - & - \\
\hline & $\begin{array}{l}\text { Honey } \\
\text { Reception }\end{array}$ & 27.000 .000 & 27.000 .000 & 27.000 .000 & 27.000 .000 & 27.000 .000 \\
\hline & $\begin{array}{l}\text { Bali Cattle } \\
\text { Reception }\end{array}$ & 16.000 .000 & 36.000 .000 & 64.000 .000 & 104.000 .000 & 168.000 .000 \\
\hline & $\begin{array}{l}\text { Difference in } \\
\text { Cattle } \\
\text { Rejuvenation }\end{array}$ & - & - & 8.000 .000 & 8.000 .000 & 8.000 .000 \\
\hline & $\begin{array}{l}\text { Total Cash } \\
\text { Inflow }\end{array}$ & 144.150 .833 & 63.000 .000 & 99.000 .000 & 139.000 .000 & 203.000 .000 \\
\hline
\end{tabular}


$\begin{array}{llllll}\text { Total }(\mathbf{A}+\mathbf{B}) & 144.150 .833 & 70.349 .167 & 125.038 .333 & 205.607 .500 & 329.096 .667\end{array}$

\section{Cash Outflow}

\begin{tabular}{|c|c|c|c|c|c|}
\hline Labor costs & 12.000 .000 & 12.000 .000 & 12.000 .000 & 12.000 .000 & 12.000 .000 \\
\hline $\begin{array}{ll}\text { Cost } & \text { of } \\
\text { depreciation } & \end{array}$ & 470.833 & 470.833 & 470.833 & 470.833 & 470.833 \\
\hline Electricity cost & 600.000 & 600.000 & 600.000 & 600.000 & 600.000 \\
\hline Cattle feed cost & 18.000 .000 & 27.000 .000 & 39.000 .000 & 57.000 .000 & 84.000 .000 \\
\hline IB Officer fee & 200.000 & 400.000 & 600.000 & 800.000 & 1.200 .000 \\
\hline Drugs cost & 1.440 .000 & 1.920 .000 & 2.880 .000 & 4.320 .000 & 6.240 .000 \\
\hline $\begin{array}{l}\text { Vitamins and } \\
\text { Minerals cost }\end{array}$ & 1.440 .000 & 1.920 .000 & 2.880 .000 & 4.320 .000 & 6.240 .000 \\
\hline $\begin{array}{l}\text { Land processing } \\
\text { cost }\end{array}$ & 1.500 .000 & - & - & - & - \\
\hline $\begin{array}{l}\text { Initial investment } \\
\text { cost }\end{array}$ & 101.150 .833 & - & - & - & - \\
\hline $\begin{array}{l}\text { Total } \\
\text { Outflow }\end{array}$ & 136.801 .666 & 44.310 .833 & 58.430 .833 & 79.510 .833 & 110.750 .833 \\
\hline $\begin{array}{l}\text { Difference in } \\
\text { Cash In \& Out }\end{array}$ & 7.349 .167 & 18.689 .167 & 40.569 .167 & 59.489 .167 & 92.249 .167 \\
\hline $\begin{array}{ll}\text { Final } & \text { Cash } \\
\text { Position } & \end{array}$ & 7.349 .167 & 26.038 .334 & 66.607 .501 & 126.096 .668 & 218.345 .835 \\
\hline
\end{tabular}

Based on the results of the annual cash flow projection within 5 years in Table 8, it can be seen that the cash position at the end of the fifth year is Rp. $218,345,833$, -. In Table 8 , information can also be obtained that at the end of the third, fourth, and fifth years, there is an inflow of cash in the form of a rejuvenation difference of Rp. 8,000,000, - / month. The magnitude of the difference in rejuvenation is obtained by selling cattles with 60 months of age ( 3 times pregnant) at the end of the third, fourth and fifth years, 2 cattles each at a price of Rp. 10,000,000, - / head, and buy back a cattle at the age of 24 months (ready to get pregnant) with 2 cattles for Rp. 6,000,000, - / head, so that there is a difference in the price of rejuvenation of Rp. 4,000,000, - / head or Rp. 8,000,000, - / year at the end of the third, fourth and fifth years.

\subsection{Projection of Profit and Loss}

The profit / loss statement is part of the financial statements of a company produced in an accounting period that describes the elements of the company's income and expenses to produce a net profit (or loss) ( Hutrema , 2010). The results of the calculation of cash flow projections can then be compiled a projection of the Profit and Loss Report on the plan for the honey beeper and Bali cattle business in Table 9 .

Table 9. Projection of Loss / Profit for Honey Beeper and Bali Cattle Annually in the Five Year Period (in rupiah)

\section{No

$$
\text { Information }
$$

\section{A Reception}

1 Honey Bee Reception

2 Bali Cattle Reception

Differnce

Rejuvenation

Total Income
1

27.000 .000
16.000 .000
-

43.000 .000
Years

2

27.000 .000

36.000 .000

27.000 .000

27.000 .000

27.000 .000

64.000 .000

104.000 .000

168.000 .000

- $\quad 8.000 .000$

8.000 .000

8.000 .000

63.000 .000

99.000 .000

139.000.000

203.000 .000 


\begin{tabular}{|c|c|c|c|c|c|c|}
\hline B & Cost & & & & & \\
\hline 1 & Labor Costs & 12.000 .000 & 12.000 .000 & 12.000 .000 & 12.000 .000 & 12.000 .000 \\
\hline 2 & Cost of Depreciation & 470.833 & 470.833 & 470.833 & 470.833 & 470.833 \\
\hline 3 & Electricity Cost & 600.000 & 600.000 & 600.000 & 600.000 & 600.000 \\
\hline 4 & Cattle Feed Cost & 18.000 .000 & 27.000 .000 & 39.000 .000 & 57.000 .000 & 84.000 .000 \\
\hline 5 & IB Officer Fee & 200.000 & 400.000 & 600.000 & 800.000 & 1.200 .000 \\
\hline 6 & Drugs Cost & 1.440 .000 & 1.920 .000 & 2.880 .000 & 4.320 .000 & 6.240 .000 \\
\hline 7 & $\begin{array}{l}\text { Vitamins and } \\
\text { Minerals Cost }\end{array}$ & 1.440 .000 & 1.920 .000 & 2.880 .000 & 4.320 .000 & 6.240 .000 \\
\hline \multirow[t]{2}{*}{8} & Land Processing Cost & 1.500 .000 & - & - & - & \\
\hline & Total Cost & 35.650 .833 & 44.310 .833 & 58.430 .833 & 79.510 .833 & 110.750 .833 \\
\hline C & Profit/Loss & 7.349 .167 & 18.689 .167 & 40.569 .167 & 59.489 .167 & 92.249 .167 \\
\hline D & $\begin{array}{l}\text { Accumulated } \\
\text { Profit/Loss }\end{array}$ & 7.349 .167 & 26.038 .334 & 66.607 .501 & 126.096 .668 & 218.345 .835 \\
\hline
\end{tabular}

Based on Table 9, it can be seen that the amount of profit projection that can be received for the first year is Rp. 7,349,167, -; the second year of Rp. 18,689,167, -; the third year of Rp. $40,569,167,-$; the fourth year of Rp. 59,489,167, -; and the fifth year of Rp. 92,249,167. Table 9 also provides information that there was a decline in profit growth in the fourth year. This is due to an increase in costs, especially in the component of the cost of cattle feed as a result of the increase in the amount of cattle production. However, this has a positive impact on the projected increase in profit received in the fifth year, which experienced a fairly high profit growth.

The amount of profit earned since the first year is influenced by income from honey beeper business activities which are carried out jointly in accordance with the concept of diversification in order to maximize the profits that will be obtained. In line with the research conducted by Herwan et al., (2020), the average income of Bali cattle business in Kambowa Sub-district is Rp. 132,889 / month, and coconut plantation farming as much as Rp. 817,368 / month, then the average income of the Bali cattle business integrated with coconut plantation farming is Rp. 950,257 / month. The diversification of Bali cattle and coconut plantations has a better profit when compared to both Bali cattle and coconut plantations which are run separately.

If the Bali cattle business is managed separately, the profit will be obtained in the fourth year onwards, while the honey beeper business has been profitable since the first year. This difference is due to the fact that Bali cattle farming is an annual source of income, requires a long production and reproduction time, while the honey beeper business according to Saepudin (2013) is a source of monthly routine income and the main focus of activities in the production system and sustainable income. On the other hand, honey bees require a shorter production time than the Bali cattle business .

\subsection{Investment Feasibility Analysis}

Project feasibility analysis is intended to determine project feasibility in terms of various investment indicators such as IRR, NPV, and payback period ( Hutrema , 2010). In line with the statement of Abadi et al., (2017) that to analyze financial feasibility it can be done using income analysis (Pd), net present value (NPV), internal rate of return (IRR), net benefit cost ratio (NBCR), break events. point (BEP), and pay back period (PBP). The analysis of the feasibility of honey beeper and Bali cattle business based on forest areas in Konawe Islands Regency aims to see whether this business plan is financially feasible or not. The analysis used in the investment feasibility assessment consists of 4 (four) analyzes, namely; Net Present Value (NPV), Internal Rate of Return (IRR), Benefit Cost Ratio (BCR), and Payback Period (PP). 
Table 10. Results of Investment Feasibility Assessment for Honey Beeper and Bali Cattle in a 5 Year Period (in rupiah)

\begin{tabular}{|c|c|c|c|c|c|c|c|c|c|}
\hline \multirow{2}{*}{ Years } & \multirow{2}{*}{$\begin{array}{c}\text { Total } \\
\text { Imcome }\end{array}$} & \multirow{2}{*}{ Total Cost } & \multirow{2}{*}{$\begin{array}{c}\text { Profit } \\
\text { Before Tax }\end{array}$} & \multirow{2}{*}{ Tax } & \multirow{2}{*}{$\begin{array}{l}\text { Net Cash } \\
\text { Flow }\end{array}$} & \multicolumn{2}{|c|}{$\begin{array}{c}\text { Discount } \\
\text { Factor }\end{array}$} & \multirow{2}{*}{$\begin{array}{c}\text { PV } \\
\text { DF 56\% }\end{array}$} & \multirow{2}{*}{$\begin{array}{c}\text { PV } \\
\text { DF 57\% }\end{array}$} \\
\hline & & & & & & $56 \%$ & $57 \%$ & & \\
\hline 1 & 43.000 .000 & 35.650 .833 & 7.349 .167 & - & 7.349 .167 & 0,641 & 0,637 & 4.711 .004 & 4.680 .998 \\
\hline 2 & 63.000 .000 & 44.310 .833 & 18.689 .167 & -1 & 18.689 .167 & 0,411 & 0,406 & 7.679 .638 & 7.582 .120 \\
\hline 3 & 99.000 .000 & 58.430 .833 & 40.569 .167 & & 40.569 .167 & 0,263 & 0,258 & 10.686 .175 & 10.483 .279 \\
\hline 4 & 139.000 .000 & 79.510 .833 & 59.489 .167 & & 59.489 .167 & 0,169 & 0,165 & 10.044 .758 & 9.791 .276 \\
\hline 5 & 203.000 .000 & 110.750 .833 & 92.249 .167 & & 92.249 .167 & 0,108 & 0,105 & 9.984 .802 & 9.670 .840 \\
\hline & & $\begin{array}{r}\text { TO } \\
\text { INI } \\
\text { NET P }\end{array}$ & $\begin{array}{l}\text { TAL PV IN } \\
\text { TIAL OUTL } \\
\text { RESENT V }\end{array}$ & $\begin{array}{l}\text { DF } \\
\text { AY } \\
\text { ALU }\end{array}$ & & & & $\begin{array}{r}43.106 .378 \\
43.000 .000 \\
106.378\end{array}$ & $\begin{array}{r}42.208 .512 \\
43.000 .000 \\
\quad 791.488\end{array}$ \\
\hline & & \multicolumn{4}{|c|}{$\begin{array}{l}\text { INTERNAL RATE OF RETURN } \\
\text { BENEFIT COST RATIO }\end{array}$} & \multicolumn{4}{|c|}{$\begin{array}{l}56,12 \\
1,002\end{array}$} \\
\hline
\end{tabular}

\subsection{Net Present Value}

Net Present Value is the difference between a series of receipts in the future after being assessed at this time (using a discount factor ) and the current expenditure (investment). An investment is said to be feasible and profitable to run if the NPV shows a positive number ( Hutrema , 2010)

This NPV or Net Present Value estimates the present value of a project, asset or investment based on expected future cash inflows and cash outflows adjusted to interest rates and the initial purchase price. Net Pressent Value uses the initial purchase price and the time value of money to calculate the value of an asset. The results of NPV calculations on the business plan of honey bee and beef cattle business show that the NPV value is positive at the discount factor rate of $56 \%$ of Rp. 106,378, -. This indicates that up to an interest rate of $56 \%$ this business plan is still feasible to be implemented. As an illustration that the average interest rate applicable sa at is in the range of $12 \%-15 \%$, so in general it can be concluded that the business of honey beeper and Bali Cattle business based forest area in Konawe Islands feasible. According to Ardalan (2012), NPV is the value that will consider the risk of future cash inflows for return on investment capital. Thus, positive NPV is accepted because it will increase firm value, on the other hand, negative NPV is rejected because it will decrease firm value, while NPV is equal to zero. the investment will not change the value of the company.

\subsection{Internal Rate of Return (IRR)}

Subsequent analyzes were used to assess the feasibility of investment in the development of honey beeper and Bali cattle business based forest area in Konawe Islands is the Internal Rate of Return (IRR). IRR is the rate of return of an investment where at that time the Net Present Value is 0 . An investment is said to be feasible and profitable to run if the IRR is greater than the assumed cost of capital ( Hutrema , 2010). NPV is the difference between the present value of cash inflows and the present value of cash outflows over a certain period of time. The IRR is used to determine the feasibility of an investment plan and corresponds to the roller discount rate used to make the net present value equal to zero. If the IRR is greater than the cost of project financing (financing interest rate), the project is feasible. Conversely, if the IRR value is greater than the financing interest, the project is not feasible. In line with the statement of the results for IRR calculation the honey beeper and Bali cattle business based forest area in Konawe Islands in Table 10 shows that the level of discount factor which the Net Present V alue (NPV) is equal to zero is equal to $56.12 \%$. This value is greater than the 
current financing interest rate, which is $12 \%-15 \%$. The results are indicating that the honey beeper and Bali cattle business based forest area in Konawe Islands feasible or feasible.

\subsection{Benefit Cost Ratio (BCR)}

Subsequent analysis used in investment appraisal effort honey beeper and Bali cattle business based forest area is the analysis of Benefit Cost Ratio (BCR). In general, BCR analysis aims to see the amount of benefits received from the implementation of an investment. BCR is an indicator used in cost- benefit analysis, which attempts to summarize the overall value for money of an investment. An investment plan as feasible to be implemented if the value of $\mathrm{BCR}>1$. The calculation result of BCR in investment appraisal effort honey beeper and Bali cattle business based forest area in Table 10 shows that the value of $\mathrm{BCR}=1.002$. This indicates that the value of BCR are larger than the first, for it can be concluded that the honey beeper and Bali cattle business based forest area Konawe Islands feasible.

\subsection{Payback Period (PP)}

Final analysis used in investment appraisal effort honey beeper and Bali cattle business based forest area in Konawe Islands is the analysis of the payback period (PP). Payback period analysis is to find out how long it will take for an investment to be returned by subtracting the amount of proceeds (net profit + depreciation + interest $(1-\operatorname{tax})+$ residual value) that will be received ( Hutrema , 2010). PP is a method of evaluating business feasibility by looking for the period required to return the amount of investment that has been issued based on the expected cash flow from the investment being funded. PP is calculated based on the initial value of the investment compared to cash flows and cumulative cash flows. The amount of PP figures reflects the length of time the investment causes the initial investment value to return. Based on the projected cash flow that has been done before (Table 10 ), it can be seen that the value of the initial investment plan of honey beeper and Bali cattle business based forest area in Konawe Islands is Rp. 101,150,833, -. Furthermore, in calculating the cash flow projection, the final cash position in the third year is Rp. 66,607,500, - and the difference between cash inflows and outflows in the fourth year is Rp. 59.489.167, -, so it can be seen that the PP value is;

$$
\begin{aligned}
\mathrm{PP}=3+ & ((101.150 .833-66.607 .500) / 59.489 .167) \\
& =3,58 \\
& =3,6
\end{aligned}
$$

The result of the calculation of the value of PBP honey beeper and Bali cattle business based forest area in Konawe Islands obtained PP value of 3.6. This indicates that the length of time for investment in which the level of acceptance can cover the entire investment cost is 3 years and 6 months. Based on the overall results of the assessment of investment criteria, it can be generally concluded that the honey beeper and Bali cattle business based forest in Konawe Islands Regency is feasible to be implemented.

\section{Conclusion}

The results of the feasibility analysis of honey beeper and Bali cattle business shows that the results of the calculation of Net Present Value (NPV) obtained a positive NPV value at the discount factor rate of $56 \%$ of Rp. 106,378, -. For investment appraisal using the Internal Rate of Return (IRR) criteria, it shows the amount of IRR where the NPV is equal to zero, which is $56.12 \%$. This value is greater than the current financing interest rate, which is $12 \%-15 \%$. Then for the investment criteria the Benefit Cost Ratio (BCR) shows the value of $\mathrm{BCR}=$ 1.002. This shows that the $\mathrm{BCR}$ value of the business is greater than 1 , therefore it can be concluded that the business plan for honey beeper and Bali cattle is feasible to be 
implemented. Furthermore, based on the Payback Period (PP) assessment criteria, it shows the length of time for investment in honey beeper and Bali cattle, where the level of acceptance can cover the entire investment cost, namely for 3 years and 6 months. Based on the overall results of the assessment of investment criteria, it can generally be concluded that the business of honey beeper and Bali cattle based on forest areas in Konawe Islands Regency is feasible to be implemented.

\section{References}

[1] Abadi, M., SAD Taridala and LO Nafiu. Evaluation of the financial feasibility of laying hens at CV. Bintani Poultry Shop Kendari. Animal Husbandry Bulletin Vol. 41 (3 ): 355-364.Ardalan, K. 2012. Payback period and NPV: Their different cash

[2] flows. Journal of Economics and Finance Education. Vol. 11 (2): 10 - 16.

[3] Herwan, LOA Sani and M Abadi. 2020. Analysis of income from the Bali Integrated Coconut Plantation Cattle Farming in Kambowa and Bonegunu Subdistricts, North Buton Regency. JIPHO Vol. 2 (1): 41 - 45.

[4] Hutrema , A . 2010. Easy Ways to Understand a Business Plan . Grasindo. www.nulisbuku.com

[5] Ministry of Forestry. 2009. Decree of the Minister of Forestry SK.338 / Menhut-VII / 2009 dated 15 June 2009 concerning the Designation of Production Forest Management Units (KPHP) and Protected Forest Management Units (KPHL) in Southeast Sulawesi Province

[6] Rachadian , FM., EA Agassi, and W Sutopo. 2013. Analysis of the investment feasibility of adding a new milling machine to the CV. Xyz. Journal J @ TI Vol. 8 (1 ): $15-20$.

[7] Saepudin R. 2013. Analysis of the sustainability of the integration model of bees with coffee gardens (Sinkolema) in order to increase honey and coffee bean production. Indonesian Journal of Animal Science Vol. 8 (1 ): 1 - 13.

[8] Sugiyono. 2014. Statistics for Research . Alfabeta. Bogor.

[9] Yuwariah , Y . 2015. The potential of agroforestry to increase income, national independence and environmental improvement. Proceedings of the 2015 agroforestry national seminar. Bandung 19 November 2015. Theme: Agroforestry innovation to support national independence. 